\title{
Remarkable Effect of Silyl Groups on Asymmetric Induction in a Conjugate Addition Reaction with $\mathrm{O}$-Methylnorephedrine-based $\mathbf{N}$-Silylamidocuprates Supporting Information
}

\author{
Steven H. Bertz, ${ }^{* \dagger}$ Craig. A. Ogle, ${ }^{*}$ and Abhinav Rastogi \\ Department of Chemistry, University of North Carolina-Charlotte, UNCC Station, Charlotte, NC 28223 USA, and \\ ${ }^{\dagger}$ Complexity Study Center, Mendham, NJ 07945 USA
}

\section{Experimental section}

All solvents used for cuprate reactions (ether, DMS, THF) were freshly distilled from sodium/benzophenone under nitrogen. Cuprate reactions were run in virgin borosilicate glass culture tubes $(2.5 \times 15 \mathrm{~cm})$, sealed with Teflon ${ }^{\circledR}$-coated silicone rubber septa. Glassware was dried in an oven $\left(180^{\circ} \mathrm{C}\right)$ for at least $10 \mathrm{~h}$. Lithium reagents were standardized by using the Gilman double titration. Chemical yields were measured by GLC with an HP 6850 gas chromatograph, equipped with an HP-1 capillary column $(30 \mathrm{~m}, 0.32 \mathrm{~mm}$ id, $0.25 \mu \mathrm{m}$ film) and FID, using the ISTD method ( $100 \mu \mathrm{L}$ decane, weighed to the nearest $0.1 \mathrm{mg})$. A Waters Associates Breeze System HPLC, equipped with a Daicel ChiralPak $^{\circledR} \mathrm{AD}$ column and dual wavelength absorbance detector, was used to determine the ee after purification of the product by thick layer chromatography on silica gel plates. NMR spectra were recorded with a JOEL ECA-500 spectrometer. Mass spectra were obtained with an Applied Biosystems ESI-TOF Mariner mass spectrometer. Specific rotations were measured with a Rudolph Research AUTOPOL IV polarimeter. FT-IR data were collected using a BIO-RAD $175 \mathrm{C}$ infrared spectrometer.

\section{Synthesis of $(1 R, 2 S)-(-)-O-m e t h y l n o r e p h e d r i n e ~(1 a)$}

Step 1 (protection): A $15.0-\mathrm{g}(100-\mathrm{mmol})$ portion of $(1 R, 2 S)$ $(-)$-norephedrine was dissolved in $100 \mathrm{~mL}$ of toluene in a $250-\mathrm{mL}$ round-bottom flask. Phthalic anhydride (14.8 g, $100 \mathrm{mmol})$ was added, and the reaction mixture was heated at reflux for 4 hours with removal of water (Dean-Stark trap). The solvent was stripped, and the crude product was collected by vacuum filtration. It was recrystallized from $95 \%$ ethanol and dried under vacuum to afford $27.0 \mathrm{~g}(96 \%)$. ${ }^{1} \mathrm{H}$ NMR (benzene- $\left.d_{6}\right): \delta 1.44$ (d, 3H, $J=7.45 \mathrm{~Hz}), 2.99$ (s, 1H), 4.73 (m, 1H), 5.12 (d, 1H, $J=$ $5.73 \mathrm{~Hz}), 6.78(\mathrm{~m}, 2 \mathrm{H}), 6.95(\mathrm{t}, 1 \mathrm{H}, J=7.45 \mathrm{~Hz}), 7.06(\mathrm{t}, 2 \mathrm{H}, J=$ $7.45 \mathrm{~Hz}), 7.32(\mathrm{~m}, 2 \mathrm{H}), 7.46(\mathrm{~d}, 2 \mathrm{H}, J=8.02 \mathrm{~Hz}) .{ }^{13} \mathrm{C}\left\{{ }^{1} \mathrm{H}\right\} \mathrm{NMR}$ (benzene- $d_{6}$ ): $\delta 13.18,53.95,75.43,122.99,126.75,128.19$, 128.44, 132.06, 133.55, 142.26, 168.41. GC-MS: $m / z$ 281, 175 (base peak), 160, 146, 130, 105, 79, 77, 51.

Step 2 (methylation): A 21.9-g (77.9-mmol) portion of the product from Step 1 was dissolved in $90 \mathrm{~mL}$ of DMF in a $500-\mathrm{mL}$ round-bottom flask. After cooling to $0^{\circ} \mathrm{C}, 6.24 \mathrm{~g}$ of $60 \% \mathrm{NaH}$ in mineral oil (156 mmol, 2.00 equiv) was carefully added in small portions over $15 \mathrm{~min}$. The reaction mixture was stirred for 15 min at $0{ }^{\circ} \mathrm{C}, 6.3 \mathrm{~mL}$ of methyl iodide (14.4 g, $101 \mathrm{mmol}, 1.30$ equiv) was added, and it was stirred for an additional $1 \mathrm{~h}$ at $0{ }^{\circ} \mathrm{C}$. Water $(300 \mathrm{~mL})$ was added, and the precipitate was collected by vacuum filtration, washed on the funnel with $300 \mathrm{~mL}$ of water, and dried under nitrogen. The crude product was recrystallized from heptane and dried under vacuum to afford $19.9 \mathrm{~g}(87 \%) .{ }^{1} \mathrm{H}$ NMR (chloroform- $d$ ): $\delta 1.66(\mathrm{~d}, 3 \mathrm{H}, J=6.87 \mathrm{~Hz}), 3.24(\mathrm{~s}, 3 \mathrm{H})$, $4.53(\mathrm{~m}, 1 \mathrm{H}), 4.71(\mathrm{~d}, 1 \mathrm{H}, J=9.74 \mathrm{~Hz}), 7.17(\mathrm{~m}, 3 \mathrm{H}), 7.25(\mathrm{~m}$,
2H), 7.59 (m, 2H), $7.65(\mathrm{~m}, 2 \mathrm{H}),{ }^{13} \mathrm{C}\left\{{ }^{1} \mathrm{H}\right\}$ NMR (chloroform- $d$ ): $\delta$ 15.88, 51.45, 65.84, 84.16, 122.93, 127.35, 128.14, 128.24, 131.52, 133.67, 138.69, 167.87. GC-MS: $m / z$ 295, 263, 174, 147, 130, 121 (base peak), 91, 77, 51.

Step 3 (deprotection): A 17.4-g (59.0-mmol) portion of the product from step 2 was dissolved in $50 \mathrm{~mL}$ of $95 \%$ ethanol in a 250-mL round-bottom flask, $2.40 \mathrm{~mL}(2.45 \mathrm{~g}, 76.6 \mathrm{mmol}, 1.31$ equiv) of hydrazine was added, and the mixture was stirred for 1 $\mathrm{h}$ at $40{ }^{\circ} \mathrm{C}$. The gelatinous white precipitate that formed was dissolved in aqueous $\mathrm{NaOH}$ (ca. $100 \mathrm{~mL}, 15 \% \mathrm{w} / \mathrm{w}$ ) at room temperature, and the product was extracted into ether, which was dried over anhydrous $\mathrm{Na}_{2} \mathrm{SO}_{4}$. The ether was stripped, and the residue was distilled (bp $115^{\circ} \mathrm{C}, 20$ torr) to give $6.63 \mathrm{~g}(68 \%)$ of 1a. $[\alpha]^{20}{ }_{\mathrm{D}}-88.37^{\circ}(0.0543 \mathrm{~g} / \mathrm{mL}, \mathrm{EtOH}) .{ }^{1} \mathrm{H}$ NMR (benzene- $\left.d_{6}\right)$ : $\delta 0.78(\mathrm{~s}, 2 \mathrm{H}), 1.06(\mathrm{~d}, 3 \mathrm{H}, J=6.87 \mathrm{~Hz}), 3.04(\mathrm{~s}, 3 \mathrm{H}), 3.08(\mathrm{~m}$, $1 \mathrm{H}), 3.72(\mathrm{~d}, 1 \mathrm{H}, J=5.73 \mathrm{~Hz}), 7.10-7.21(\mathrm{~m}, 5 \mathrm{H}) .{ }^{13} \mathrm{C}\left\{{ }^{1} \mathrm{H}\right\} \mathrm{NMR}$ (benzene- $\left.d_{6}\right): \delta 19.56,52.29,56.71,89.69,127.72,128.19$, 128.32, 140.10. FT-IR $\left(\mathrm{cm}^{-1}\right)$ : $3396(\mathrm{~m}), 2920(\mathrm{~m}), 1702(\mathrm{~m})$, $1509(\mathrm{~m}), 1440(\mathrm{w}), 1215(\mathrm{~m}), 1087(\mathrm{w}), 860(\mathrm{w})$. GC-MS: $\mathrm{m} / \mathrm{z}$ 134, 121, 105, 91, 77 (base peak), 65, 51 .

\section{Typical cuprate preparation and reaction}

A 330.2-mg (2.00-mmol) portion of 1a was dissolved in $5 \mathrm{~mL}$ of freshly distilled solvent (ether, DMS or THF) under argon. The solution was cooled to $-78{ }^{\circ} \mathrm{C}$ (dry ice/acetone bath) for 6 min, and $2.00 \mathrm{mmol}$ of BuLi was added. The reaction mixture was stirred at $-78^{\circ} \mathrm{C}$ for $6 \mathrm{~min}$, warmed to $0{ }^{\circ} \mathrm{C}$ (ice bath) for 6 min, and cooled to $-78{ }^{\circ} \mathrm{C}$ (6 $\left.\mathrm{min}\right)$. A $2.00-\mathrm{mmol}$ aliquot of silyl chloride 2 was added, and the reaction mixture was stirred at -78 ${ }^{\circ} \mathrm{C}$ for $6 \mathrm{~min}, 0{ }^{\circ} \mathrm{C}$ for $6 \mathrm{~min}$, and $-78^{\circ} \mathrm{C}$ for $6 \mathrm{~min}$. Another 2.00 mmol aliquot of BuLi was added, and the reaction mixture was stirred at $-78{ }^{\circ} \mathrm{C}$ for $6 \mathrm{~min}, 0{ }^{\circ} \mathrm{C}$ for $6 \mathrm{~min}$, and $-78^{\circ} \mathrm{C}$ for $6 \mathrm{~min}$ to give a solution of 4 .

The solution of $4(7 \mathrm{~mL})$ was transferred via syringe or cannula to a suspension of $\mathrm{TCu}(\mathrm{T}=\mathrm{Me}$ or $\mathrm{Bu})$ in $7 \mathrm{~mL}$ of the same solvent at $-78^{\circ} \mathrm{C}$. (The $\mathrm{TCu}$ had been prepared by adding 2.00 mmol of TLi to $381 \mathrm{mg}, 2.00 \mathrm{mmol}$, of CuI suspended in $6 \mathrm{~mL}$ of solvent at $-78{ }^{\circ} \mathrm{C}$, stirring at $-78^{\circ} \mathrm{C}$ for 6 min, annealing at $0{ }^{\circ} \mathrm{C}$ for $3 \mathrm{~min}$, and cooling to $-78^{\circ} \mathrm{C}$ for $6 \mathrm{~min}$.) The reaction mixture was stirred at $-78{ }^{\circ} \mathrm{C}$ for $6 \mathrm{~min}$, annealed at $0{ }^{\circ} \mathrm{C}$ for $6 \mathrm{~min}$, and cooled to $-78{ }^{\circ} \mathrm{C}$ (6 $\left.\mathrm{min}\right)$. A $400.0-\mathrm{mg}$ (1.92-mmol) portion of chalcone, dissolved in $5 \mathrm{~mL}$ of solvent in a $10-\mathrm{mL}$ syringe, was cooled with dry ice and added slowly down the sides of the glass tube. After stirring for $2 \mathrm{~h}$ at $-78^{\circ} \mathrm{C}$, the reaction mixture was allowed to stand for $18 \mathrm{~h}$ at $-78{ }^{\circ} \mathrm{C}$ in a low temperature freezer. It was quenched with $4 \mathrm{~mL}$ of Ar-sparged 3-M aqueous $\mathrm{NH}_{4} \mathrm{Cl}$. The reaction vessel was vented with a syringe needle and warmed by hand to melt the contents as fast as possible. The organic layer was separated immediately and dried over anhydrous $\mathrm{Na}_{2} \mathrm{SO}_{4}$. 